\title{
Cycles of Beauty Culture: Ethnography of Beauty Clinics Commodification
}

\author{
Sri Murlianti ${ }^{\bowtie}$ \\ Sociology Department, Mulawarman University, Kalimantan Timur, Indonesia
}

Permalink/DOI: http://dx.doi.org/10.15294/komunitas.v6i1.3312

Received : July 2014; Accepted: August 2014; Published: September 2014

\begin{abstract}
Skin care is not a completely new in beauty treatments. Previously there have been other types of cultural industry which also adopted the medical science, such as cosmetic and beauty salon industries. But, skin care beauty clinic successfully introduces the services of beauty treatments which are considered the healthiest. This paper is a summary of the research on how beauty clinic quickly became a part of everyday life of its consumers. The research focused on Natasha Skin Care, a most popular beauty clinic in Indonesia at the moment. According to Richard Johnson, the process of a culture industry reaches the society through a communication that in form a pattern cyclic communications. The stages in the pattern are interconnected but slipped, each stage is affecting others but are not specified in an uncertain manner; between the producer of culture industry with its consumers. This study is a multidiscipline research using three methods of interpretation namely ethnography, discourses analysis, and social hermeneutic study.
\end{abstract}

\begin{abstract}
Abstrak
Klinik kecantikan bukanlah budaya yang benar-benar baru dalam perawatan kecantikan. Sebelumnya telah ada jenis industri budaya lain yang juga mengadopsi ilmu kedokteran, seperti industri kosmetik dan salon kecantikan. Namun klinik kecantikan sukses menyandang predikat sebagai jasa perawatan kecantikan yang dianggap paling sehat. Tulisan ini merupakan rigkasan penelitian tentang bagaimana klinik kecantikan begitu cepat menjadi bagian hidup sehari-hari masyarakat konsumennya. Fokus penelitian ini adalah Natasha Skin Care, sebuah klinik kecantikan paling popular di Indonesia saat ini. Menurut Richard Johson proses sebuah industri budaya sampai pada masyarakat konsumennya melalui komunikasi yang timpang, membentuk pola komunikasi siklik, saling terhubung namun penuh dengan keterpelesetan, saling mewarnai namun tidak menentukan secara pasti antara produsen industri budaya dengan masyarakat konsumennya. Penelitian ini ditempuh dengan kerja multidispliner, menggunakan setidaknya tiga metode interpretasi, yaitu etnografi, analisis wacana dan hermenuitik sosial.
\end{abstract}

Keywords: beauty; consumer culture; communication ethnography; culture industry

How to Cite: Murlianti, S. 2014. Cycles of Beauty Culture: Ethnography of Beauty Clinics Commodification. Jurnal Komunitas, 6(2):327-335. doi:http://dx.doi.org/10.15294/komunitas.v6i2.3312

(c) 2014 Semarang State University. All rights reserved 


\section{INTRODUCTION}

Beauty clinics such as Natasha must not be naively understood as the application procedures of clinical discipline practices into the beauty care services practice. The concept of 'clinic' does not simply refer to the value for the health. It is employed to represent the value of cultural signs that indicates a certain social class for the consumers. The primary emphasis of this study is to describe how beauty clinic is so quickly accepted by millions of consumers and become part of their daily activities. This study also tries to find out how this beauty clinic is so easily accepted by the people of Indonesia who have diverse cultural background and how it is able to shift a variety of ideal beauty concept, complete with its treatment traditions.

According to Johnson, the products of cultural industries commodities are described to reach its consumers through cyclic communication consisting of four stages in the circuit. The circuit is depicted in the form of a cyclic chart as follows chart 1.

The communication between cultural industry producers with their consumers is not a direct and equal communication that produces a reciprocal pattern. This communication is full of gaps and forming a cyclic pattern. The first two stages illustrate how the cultural industry powerfully manipulates the buyers by shaping and directing the consumers' understanding. Conditions of production not only includes the material of production and the organization of labor, but also the media and stock elements of diverse cultural practices of life. The next two stages illustrate how the poor society, who is lack of power, reads the trend based on their own subjectivity and experiences. Each box represents a stage in the circuit.

The producers or owners of a beauty clinic, with their abundant capital, are powerfully directing consumers' understanding upon the strengths of their commodities. They can buy the capitals in the form of cultural elements of various practices of life. These cultural elements are used as symbolic capitals to build new distinctions that differentiate their commodities with the other beauty service business. Cultural elements of clinical practice are combined

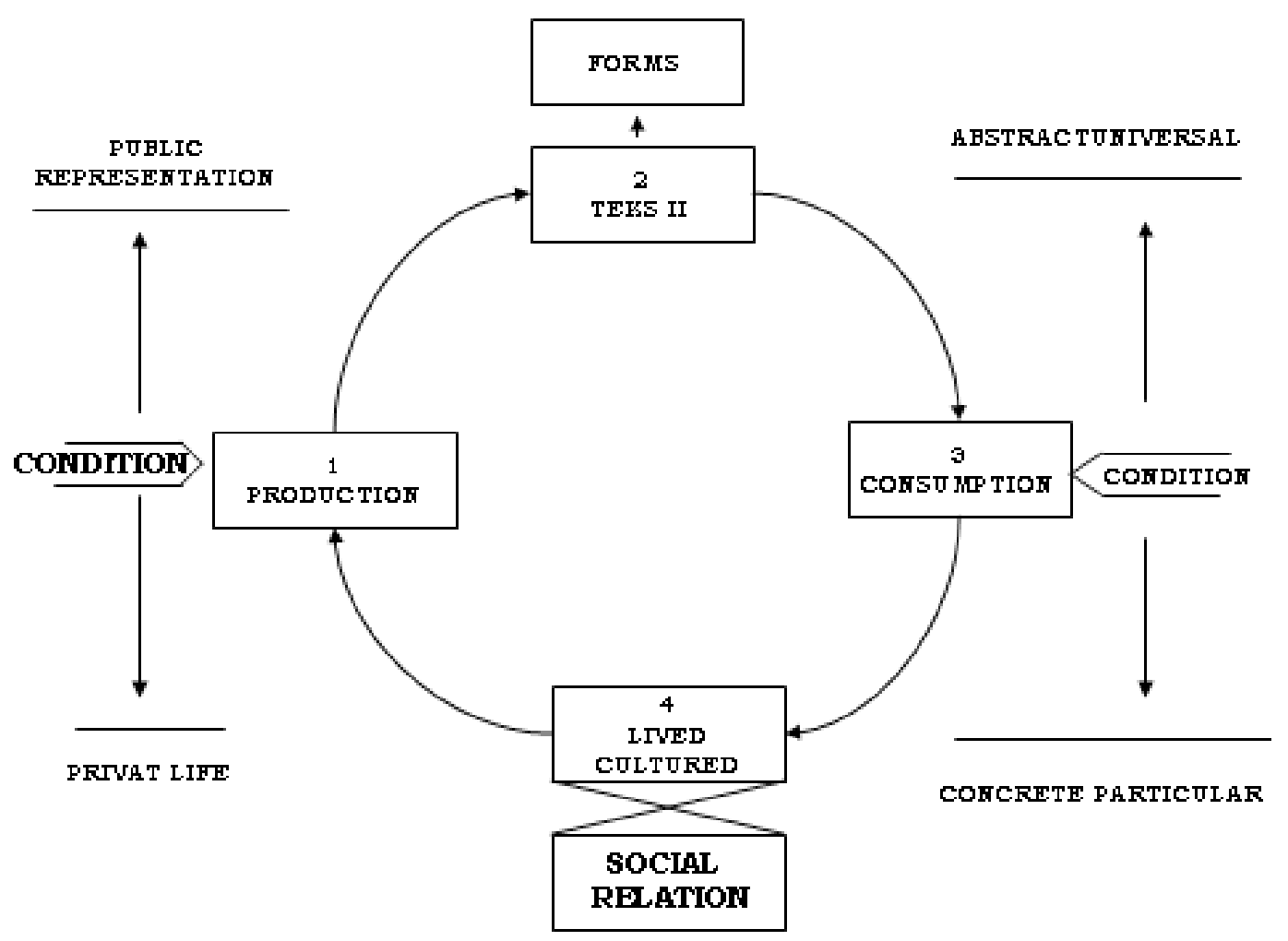

Chart 1. Circuit of Capital, Circuit of Culture 
with the cultural elements of traditional palace culture, intellectual culture and modern culture; forming a new commodity of beauty clinic. The cultural elements of clinical practice are set on the surface to highlight the character of medical image as the healthiest beauty treatment service.

Understanding how Natasha can be part of the daily life of millions of consumer means following the journey of this cycle. It starts with how it is created in the creative production, how it is promoted on textual moment, how it is interpreted by the public at the moment of consumption, and how it is used by consumers at the moment of the live cultured. Each moment can be studied in-depth separately, but the researcher chooses to explore this whole moment of cultural production.

\section{PRODUCTION STAGES}

The first stage in the communication circuit of beauty clinic cultural commodity is the moment of production. This stage is where the couple of Dr. Fredi Setiawan and his wife Onny Tantri as the agents of the cultural industry offer the package of new commodity namely beauty clinic. The whole appearance of practice in Natasha clinic is the first text building production stage. The first text building creates a cultural commodity packaging of beauty clinic named Natasha Skin Care. This beauty clinic is seen as a new practice in the habitués of beauty treatments. To understand the beauty clinic as a practice, researcher used the formula of Bourdieu practices; practice $=$ (habitués $\mathrm{x}$ capital) + domain. Ethnographic techniques could be seen from the capitals that are used to organize the whole practice of the beauty clinic services.

The interpretation moment of production begins with classifying the production of cultural elements that are used as capital- to build this culture industry practice according to its origin and usefulness in Natasha. As a new cultural practice, beauty clinic is a combined practice of the various elements of the cultural practices from diverse cultural contexts, as explained in table below:
Beauty Clinic is a practice of beauty treatment service that uses a combination of cultural elements of diverse cultural contexts. What constitutes the real beauty clinic is a joint articulation of cultural elements from diverse aspects of cultural practices; starting from the elements of traditional palace culture, the modern architecture culture, the beauty salons practice, medical practice, and the intellectual culture. The beauty clinic practice combines the behavioral codes of the various practices of life from the consumers or visitors. Being consumer of beauty clinic, visitors are required to practice the combined behavior including graceful traditional aristocrats, discipline modern intellectuals, medical literacy, and being adherent.

The cultural elements of clinical practice dominate the composition of clinical appearance. The dominance of the clinical discipline elements order is used as capital symbolic, serving as the evidence to declare themselves as a healthy treatment practice. This dominant composition highlights the appearance of clinical disciplines as possessing the image of medical literacy. Visiting the beauty clinics provide the sense of medical literacy. By visiting beauty clinic, consumers are led to obediently follow them just like the procedure of treatment in the hospital. Each consumer must register through the card member to receive control card data of patients. Furthermore, each procedure looks like a clinical treatment procedure in which the consumer must pass through consultation with a doctor before deciding to buy the type of care and cream.

This view does not always guarantee the health commodities they offer, both the take-away products and the care services at the clinic. Natasha cream products itself experienced the market withdrawal as they are put in the list as a dangerous product by Food and Drugs Administration (BPOM) Not a few consumers who eventually go to a dermatologist because they experience skin suffering, from a mild irritation to the most serious irritation. However, this procedure gives the image of medical literacy, no matter how high the level and status of the con- 
Table 1. Beauty Clinic Practice

\begin{tabular}{|c|c|c|}
\hline Capital & Detail & Use \\
\hline Symbolic & $\begin{array}{l}\text { doctor, doctor consutancy, } \\
\text { doctor prescription, medicine, } \\
\text { patients' control card, drug } \\
\text { store, chemist, patients' room, } \\
\text { advanced medical technology, } \\
\text { treatment }\end{array}$ & $\begin{array}{l}\text { Medical literacy: } \\
\text { Choosing a 'healthy' beauty treatment, } \\
\text { Handled by leading dermatologists } \\
\text { Detected with advanced dermatology tech- } \\
\text { nology } \\
\text { Using a treatment cream from doctors' pre- } \\
\text { scription }\end{array}$ \\
\hline Symbolic & $\begin{array}{l}\text { Get the door opened by the } \\
\text { staffs, being served with a soft- } \\
\text { spoken language, being re- } \\
\text { spected }\end{array}$ & $\begin{array}{l}\text { The aristocrats image of traditional palace } \\
\text { era }\end{array}$ \\
\hline Culture & Beautician & $\begin{array}{l}\text { Medical Literacy: } \\
\text { As 'nurses' that help the duty of doctors dur- } \\
\text { ing treatment }\end{array}$ \\
\hline \multirow[t]{3}{*}{ Material } & $\begin{array}{l}\text { Clean and well-maintained } \\
\text { building, modern-styled for } \\
\text { the interior and exterior de- } \\
\text { sign, various cool drinks }\end{array}$ & $\begin{array}{l}\text { Modern aristocrate image: } \\
\text { Being served in a clean and well-maintained } \\
\text { building } \\
\text { Queuing orderly, not rowdy } \\
\text { Taking drinks appropriately }\end{array}$ \\
\hline & $\begin{array}{l}\text { Television, Natasha Magazine, } \\
\text { newspapaer, Mandala Maga- } \\
\text { zine }\end{array}$ & $\begin{array}{l}\text { Intelectual Image: } \\
\text { Killing the queuing time by reading } \\
\text { Updating the news info }\end{array}$ \\
\hline & Cosmetic & $\begin{array}{l}\text { Opting consumers who are still interested in } \\
\text { decorative cosmetic }\end{array}$ \\
\hline
\end{tabular}

Source: adapted from the collection of personal data

sumers themselves, they will finally let the experts (doctors) to handle their beauty care rituals.

\section{Texts stages}

In the text moment, the owners of Natasha, with their power of capital, are deploying a variety of media, attributes, models and knowledge to promote this beauty clinic. At this moment, bombing promotion on beauty clinic is done in various ways, in a variety of public and private spaces, with diverse view points of truth, complete with their stunning models, offering tempting gifts or discounts. In the discourse, Natasha is surrounded by the diverse viewpoints of truth; it is discoursed as "true" from any point of views. The Natasha discourse attributes influences the public and private space in Yogyakarta at any time. The effects of the discourse bombardier were felt at the time of this study. Researcher witnessed that wherever and whenever researcher walked, there was always talk about Natasha skin care clinic.

In this promotional stage, Natasha discourse beauty clinic is sent to the community as an educational institution that teaches the general public about healthy beauty treatments. Beauty clinic is promoted as if it is the only model of beauty care services practice that ensures the health of the consumers. Researcher used Foucault's concept of discipline and discursive practices to explain the strategy and the struggle of the culture industry players in promoting the beauty clinic. In the discourse, Natasha is described as having a lot of value of kindness and truth. Education about healthy beauty treatments of Natasha style is implemented in a variety of public and private space; starting from the Natasha clinics, streets to the cli- 
Tabel 2. Discorse of Natasha's Truth

\begin{tabular}{|c|c|c|}
\hline Truth Discourse & Symbolic Evidence & Forms of Discourse \\
\hline Healthy, safe & Dr Fredy Setyawan & advertisement \\
\hline $\begin{array}{l}\text { Advanced, sophisti- } \\
\text { cated }\end{array}$ & Dermatology Laser & advertisement \\
\hline $\begin{array}{l}\text { Resulting in "natu- } \\
\text { ral beauty" after the } \\
\text { treatment }\end{array}$ & The winners of Natasha's Face & $\begin{array}{l}\text { advertisement, poster, billboard, } \\
\text { website page, illustration of mag- } \\
\text { azine articles }\end{array}$ \\
\hline $\begin{array}{l}\text { Religious, brilliant, ro- } \\
\text { mantic, hard woork- } \\
\text { ing experts }\end{array}$ & $\begin{array}{l}\text { Fredi, Onny, their children, } \\
\text { pink, luxurious haouse }\end{array}$ & Article of "The origin of" Natasha \\
\hline $\begin{array}{l}\text { Style and fashion liter- } \\
\text { ate }\end{array}$ & $\begin{array}{l}\text { Event Organizer, top per- } \\
\text { forming artists and singers, } \\
\text { choreographer, Ambarukmo } \\
\text { Plaza, famous bands }\end{array}$ & $\begin{array}{l}\text { Nataha Face Contest, , } 100 \text { wom- } \\
\text { en enchantment, naasha Teen } \\
\text { Expression, Natasha }\end{array}$ \\
\hline Naural beauty & Natasha models & $\begin{array}{l}\text { Brochure, Poster, advertisement, } \\
\text { Articles, Natasha Magazine }\end{array}$ \\
\hline Go-international & $\begin{array}{l}\text { Miss Universe, Putri Indo- } \\
\text { nesia, foreign dermatologist, } \\
\text { Fredi-Onny, The winners of } \\
\text { Natasha's Face }\end{array}$ & Advertisment, Article \\
\hline Halal & $\begin{array}{l}\text { Umroh, Hajj, Fasting Month, } \\
\text { Orphanage and Orphans }\end{array}$ & $\begin{array}{l}\text { Advertisment, Doctor recruit- } \\
\text { ment using arabic name and hajj, } \\
\text { breaking the fasting together }\end{array}$ \\
\hline blessed & $\begin{array}{l}\text { Priest, The Book of Wisdom, } \\
\text { he stories of global celebrities }\end{array}$ & $\begin{array}{l}\text { Rubric 'Oase' in Natasha Maga- } \\
\text { zine }\end{array}$ \\
\hline Cheap, safe & gifts, discount, gadget, & Advertisement, Poster, Billboard \\
\hline
\end{tabular}

Source: adapted from the collection of personal data

nics, city main roads, schools, colleges, orphanages, print and online media, radio, television, and Natasha website. The symbolic cultural elements from the diverse cultural sphere are gradually collected and used as a symbolic evidence of the merits and truth that will be highlighted. With 'symbolic evidence, the discourse of truth and excellence of Natasha's commodities emerge as a natural truth: true by nature. The following table depicts how these symbolic capitals are used to create Natasha commodities discourse:

Natasha is viewed from many points of truth, in many ways, in a variety of public spaces that exist, even reaching the private family sphere. Various ways and evidences are used to talk about the truth and superiority complex. In Yogyakarta, almost certainly no public space missed the mark of Natas- ha promotion. Some of these are shown in the following figure:

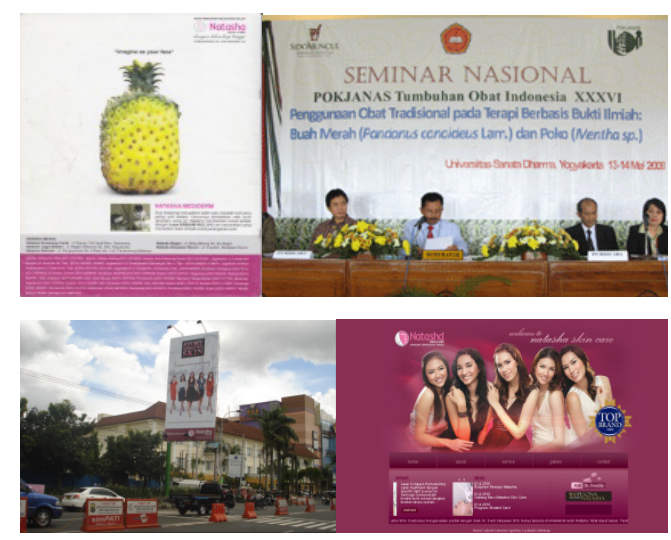

Figure 1. Some forms of Natasha Discourse Strategy

Explanation: From left to right, advertisements in Natasha magazines, Redi became a 
speaker on campus of Sanata Dharma, Natasha Advertisement at Jl Laksda Adisucipto, and The Natasha Website Cover with the winners of Natasha Face event as models.

Truths that are built into this discourse develop gradually according to the ability of symbolic capital accumulation that will be used as evidence. In the early days of its development, the popularity of Dr. Fredi as an aesthetic dermatology expert in Yogyakarta becomes a major symbolic evidence of Natasha excellence. Fredi becomes a proof toward the truth over the discourse of the healthiest and safest beauty clinic. Then, Natasha continues to collect the next symbolic capitals to strengthen the discourse. The investment of sophisticated aesthetic dermatology equipments worth billions of dollars serves as the next 'proof' to assert itself as the most advanced beauty clinic. The popularity of Fredi, the beauty of Onny, and aesthetic dermatology laser collection are the major collection of Natasha's symbolic evidence which immediately disqualifies their competitors. These advantages are further enhanced with the existence of Natasha's face contest. This event selects the Natasha's consumers who have natural beauty, both in terms of face, skin, and body posture. The winner of this event will then be an ambassador for Natasha and as the evidence of the treatment result in Natasha.

In its development, the symbolic capitals which are accumulated to discourse the truth about Natasha do not solely come from the cultural aspect of beauty treatments and clinical practice. The symbolic capitals of culture spheres which are previously considered unrelated to the problem of appearance are now being the discourse instruments for Natasha; starting from the symbolic capitals in education (seminars, workshops, dialogues), religion (image $h a-$ lal, fasting, pilgrimage, blessed image, etc.), cultural family (family gathering) and so on. To reach large Muslim consumers, some Islamic event are organized such as umrah, hajj/ pilgrimage, breaking fasting together, until giving social contribution to some orphanages. These smart moves are used to highlight the image of halal, especially dealing with the absence of the label 'halal' from MUI which is the main legitimate organization to issue halal products in Indonesia.

The regular visit of Miss Universe in Indonesia is also used as the symbolic capital accumulation of Natasha discourse. The global beauty icons who previously serve as the routine discourse instrument of giant cosmetic company of Indonesia (PT Mustika queen) is now taken over by by Natasha. Since 1998, the visit of Miss Universe shifted to Natasha. Soon, the discourse attributes of Natasha are decorated by the image of these global winning women. By doing this, Natasha seems to officially declare itself as the only beauty clinic that has been "go-international"; and the visit of Miss Universe is used as the evidence. Until this study finished, Natasha has symbolic capitals of almost all existing cultural domain; starting from the aspect of health, beauty, education, religion, family. Almost all the symbolic elements have been mastered and used to discourse the Natasha's truth. In the discourse, Natasha is described as "right" from any point of views and is suitable for everyone.

At this textual moment, Natasha becomes abstract in nature. Natasha appears as a magnificent building surrounded by modern culture texts. It becomes a major public issue; the promotion is associated with the symbols of modern society for the upper middle class. In a variety of discourses, Natasha is described as the most advanced beauty care, being handled by advanced dermatology experts, safe, producing natural beauty, and the only beauty clinic that is always visited by the winner of Miss Universe. Bombardment of this discourse in all public and private space ultimately brings victory. This victory marks the success to achieve the Top Brand Award. Until this study finished, Natasha has won the Top Brand award three times in a row for the category of beauty clinic. This means that the bombardment of discourse Natasha has successfully put this beauty clinic in the public. At this point, the production of Natasha discourses has become public knowledge dealing with the natural beauty clinic. Talking a beauty 
clinic is talking about Natasha.

\section{CONSUMPTION STAGES}

In the third stage, the consumers interpret Natasha according to their logic and their own subjectivity. None of the customers that researcher interviewed are that ignorant to believe all the advantages in the promotion of Natasha. But no one is really active and intelligent to look for the essential truth of the discourses of Natasha. Most of them are looking for healthy beauty care information from the experience of their close friends or relatives. But they find the reality that with whomever they talk about healthy beauty care problems, Natasha is always mentioned. However, their interpretation of Natasha varies, depending on the collection of capitals and life experience. In the interpretation of the consumer, Natasha has a variety of meanings; starting as a healthy beauty treatment, expensive, producing a natural beauty, there are some people who think Natasha as a dangerous treatment.

The third stage is the stage of consumption, which is when the active consumers interpret Natasha commodities according to their own subjectivity. These stages form a third text in the form of individual interpretation from Natasha consumers. Researcher used the Hermeneutic Social Methods by Paul Ricoeur to understand the third and fourth cycles of stage position of beauty clinic commodities. How consumers interpret and use the product as a beauty clinic text can be understood by the concept of Ricoeur. According to him, the position of reader in front of the text is to take some and reject others. The concept of Ricoeur's appropriation is to explain the position of the consumer in the face of cultural texts. Appropriations can be regarded as an act of 'taking the most of what are considered useful and discard the others.' Ricoeur explains that the position of the text before the reader is to digest, not to swallow, but also not completely discard everything.

In this study, the interviewees are not passive, ignorant and powerless readers. But they are also not fully active. They interpret according to the logic, knowledge and experience of each individual life. The results of individual understanding fully form individual text that varies according to their life experience. There is no standard pattern that can be used here. Experience, knowledge, social positions of the various domains of life that have been a history of one's life contributes to set up individual interpretation. In understanding the individual interpretation, we must also understand how complex dispositions and individual knowledge that are used to read and interpret the beauty clinic. A further investigation to analyze several trajectories (movement) class either horizontal or vertical which forms the individual dispositions and models of their understanding is needed.

In understanding the consumer, beauty clinic has expanded meaning. In understanding the consumer, a beauty clinic is interpreted variously according to the subjectivity of the consumer. Each customer has their own understanding of what a beauty clinic is. Both have an understanding as a healthy beauty care services. The models of consumers' understanding are characterized by the differences in life capitals and experience from each consumer. Beauty clinic is viewed from different sides according to the subjectivity of the consumer.

In understanding the consumer, beauty clinics become a cultural symbol that has a various forms of explanation. Explanation of the consumer about what the beauty clinic is the accumulation of consumers' knowledge toward diverse aspects of their life struggle; articulation of knowledge about health, beauty, religion, feminism, and some traditional cultural knowledge. Various consumers from diverse backgrounds contribute to the creativity of a beauty clinic business.

When performing in-depth interviews with consumers, researcher saw a situation where discourse of Natasha as a 'healthy' beauty clinic has become a sort of natural truth. None of the informants that researcher interviewed became consumers of Natasha because of the influence of the direct encounter with the productions of Natasha discourse. They first asked for consideration of their close friends or relatives when loo- 
king for a healthy beauty treatment. But generally, they faced situations wherever and whenever they started a conversation about healthy beauty clinic, Natasha is always mentioned. It is not that the productions of repressive discourse that drives consumer to buy the product, but the naturalized truths through the discourse commodity is the one that makes Natasha look so useful and healthy. The effects of discourse bombardment do not fool consumers about healthy beauty clinic, but it certainly wins the public conversation about beauty clinic. The dominance of public discussion sends the message that this is actually a powerful weapon, as if the consumer with the collection and interpretation of knowledge itself realize that Natasha is the best beauty clinic.

\section{LIVED CULTURE STAGES}

The fourth text is the text of individual consumers in using beauty clinic products in their everyday life. This stage will reveal individual consumers explanation about the use of commodities as part of activities of daily living. Here the beauty clinic becomes part of a collection of objects for individual consumers. It is used in various ways as part of a marker to express an individual's personality. The consumers select the products that will be purchased by using complex capitals collected along the trajectory of their individual lives. Capitals customers include financial capital and knowledge capital derived from their experience. Financial capital strength is dominantly influential factor to select the products, but does not always determine the choices of consumers. Wealthy consumers do not necessarily buy all kinds of the offered package care. Instead, poor financial capital does not always make a person to buy the products which is not covered by their financial capabilities.

In the consumer creativity, beauty clinics are used as symbols to express diverse cultural claims of individual personality traits. The individual personality traits are not the pictures of essential character of a person carried over from the birth until death. What is claimed to be individual personality is not more than a character that is chosen by someone to declare who he/she is. Consumers who have similar life experiences in some areas can claim to have different personalities. Types of personality of a person cannot be claimed as a way how a person who offers himself before others. The individual personality characters of the consumer are used to explain the reasons for selecting products of beauty clinic. In the consumer creativity, beauty clinics can be used as cultural capitals to express the character of diverse personalities; starting from consumers who claim have natural personality, and devout Muslim, rich housewife, urban success, to dynamic personality person. All consumers declare to fit using beauty clinic.

The moment of lived cultured is not the final stage from Natasha commodity cycle. The model of consumers use in everyday life is reviewed back by the management Natasha as the producer of product manufacturers in order to improve their cultural commodity. It is not unusual for producers of cultural industries that they have a division of consumer surveys to constantly explore their customer satisfaction data. The results of the survey will serve as the raw materials to be processed together with the cultural elements of diverse cultural context, to rebuild the models which are considered as better commodity and more approaching community needs of consumers. This process will form the first text of commodity again, namely the production of text. The compiled text production will be reviewed in the stage of lived cultured to make improvements in previous commodity results. Furthermore, the commodities production stages will be re-introduced in the promotion stage. And commodities will again experience the cyclic communication to be delivered to the public.

\section{CONCLUSION}

The idea of using clinical cultural elements in beauty commodities is not entirely owned by beauty industry players of beauty clinic. Previously, there had been beauty treatment commodities which also claimed to adopt the medical knowledge. Beauty clinic takes the idea of the clinical knowledge use 
with a new co-modification strategy. It does not only adopt the medical knowledge, but also clinical procedures which are normally offered for the patients in the hospitals. By administering this procedure, beauty clinic can even surpass two prebious models of beauty clinic commodities: cosmetics and beauty salon industry.

Commodity of cultural industries such as Natasha Skin Care is reaching costumers through four stages of communication of commodity cycle. Each stage produces a specific text, which can affect each other, but cannot be certainly determined by the stage of the next cycle. It can also influence but cannot determine the certainty of formation of the text at a later stage. Communication process takes place in a cyclicdynamic process -interconnected but filled with odds and inequality, full of intrigue both for consumer and producer side. The imbalance of power between the two makes the owner of a beauty clinic always read the reintroduction of any deficiencies or criticism of the user to continuously improve its commodity. Criticism users and all leading edge developments at the level of lived culture serves as the raw materials that will be re-processed to enhance the further the stages of production of commodities.

\section{REFERENCES}

Bordieu. 1979. Distinction, A Social Critic of The Judment $O f$ Taste. Routlugde.

Foucault. M. 1984. The History of Sexuality. Penguin Book: London.

Fiske, J. 1987.Understanding Popular Culture. London, Unwin Hyam

Haryatmoko. 2003. Landasan Teoritis Gerakan Sosial Menurut Pierre Bordieu; Menyingkap Kepalsuan Budaya Penguasa. Majalah Basis. Ed. November-Desember 2003, Hal : 4-23

Haryatmoko. 2002. Kekuasaan Melahirkan Anti Kekuasaan, Menelanjangi Mekanisme dan Teknik Kekuasaan Bersama Michel Foucault. Majalah Basis, Ed. Januari-Februari 2002: hal 8-21.

Ibrahim, A.S. 1994. Panduan penelitian Etnografi Komunikasi. Usaha Nasional: Surabaya.

Ricoeur, P. 1979. The Interpretation Theory, Discourse and the Surplus of Meaning. The Texas Christian University Press.

Ricoeur, P. 1981. Hermeneutic AND THE human Sciences, Essays On Language, Action and Interpretation. Cambridge University Press.

Sumaryono, E. 1999. Hermeneutik, Sebuah Metode Fil- 